\title{
Training and practice of nurses in Primary Care management: perspectives of Schön's Theory
}

\author{
Formação e prática do enfermeiro na gestão da Atenção Primária: perspectivas da Teoria de Schön \\ Formación y práctica de enfermeras en la gestión de Atención Primaria: perspectivas de la Teoría de Schön
}

\section{Suellen Gomes Barbosa Assad' ORCID: 0000-0002-4911-3837 \\ Geilsa Soraia Cavalcanti Valente' ORCID: 0000-0003-4488-4912 \\ Silvia Cristina Pereira dos Santos' ORCID: 0000-0002-1612-3334 \\ Elaine Antunes Cortez' ORCID: 0000-0003-3912-9648}

'Universidade Federal Fluminense. Niterói, Rio de Janeiro, Brazil.

How to cite this article: Assad SGB, Valente GSC, Santos SCP, Cortez EA. Training and practice of nurses in Primary Care management: perspectives of Schön's Theory.

Rev Bras Enferm. 2021;74(3):e20200461. https://doi.org/10.1590/0034-7167-2020-0461

Corresponding author:

Suellen Gomes Barbosa Assad

E-mail: suellengomesbarbosa@gmail.com

EDITOR IN CHIEF: Antonio José de Almeida Filho ASSOCIATE EDITOR: Andrea Bernardes

Submission: 07-09-2020 Approval: 01-04-2021

\begin{abstract}
Objectives: to analyze the process of permanent professional training of Primary Health Care nurse managers from the perspective of reflective practice theory, built by Donald Schön. Methods: this is a theoretical-reflective study. Results: the findings apply to nurse managers' practice to deal with the dilemmas that present themselves in the professional routine according to their knowledge, skills and attitudes, anchored in the reflection-inaction movement, which unites the process of permanent and practical training reflective, favoring the development of skills relevant to management. Final Considerations: nursing health managers, during their ongoing training process, can develop skills to act effectively in Primary Care, reflecting in practice and on practice, deciding on the need to remain in training to address the issues arising from that same practice.

Descriptors: Professional Competence; Professional Practice; Population Health Management; Nurses; Primary Health Care.
\end{abstract}

\section{RESUMO}

Objetivos: analisar o processo de formação profissional permanente do enfermeiro gestor da Atenção Primária à Saúde na perspectiva da teoria de prática reflexiva, construída por Donald Schön. Métodos: trata-se de estudo teórico-reflexivo. Resultados: os achados se aplicam à prática do enfermeiro gestor para lidar com os dilemas que se apresentam no cotidiano profissional de acordo com os seus conhecimentos, habilidades e atitudes, ancorados no movimento de reflexão-na-ação, que une o processo de formação permanente e a prática reflexiva, favorecendo o desenvolvimento de competências pertinentes à gestão. Considerações Finais: os enfermeiros gestores de saúde, durante seu processo de formação permanente, podem desenvolver competências para atuar efetivamente na Atenção Primária refletindo na prática e sobre a prática, decidindo sobre a necessidade de permanecer em formação para dar conta das questões advindas dessa mesma prática.

Descritores: Competência Profissional; Prática Profissional; Gestão em Saúde; Enfermeiras e Enfermeiros; Atenção Primária à Saúde.

\section{RESUMEN}

Objetivos: analizar el proceso de formación profesional permanente de los enfermeros que gestionan la Atención Primaria de Salud desde la perspectiva de la teoría de la práctica reflexiva, construida por Donald Schön. Métodos: se trata de un estudio teórico-reflexivo. Resultados: los hallazgos se aplican a la práctica de las enfermeras gestoras para afrontar los dilemas que se presentan en la rutina profesional de acuerdo a sus conocimientos, habilidades y actitudes, anclado en el movimiento de reflexión-en-acción, que une el proceso de formación continua y práctica reflexiva, favoreciendo el desarrollo de habilidades relevantes para la gestión. Consideraciones Finales: los enfermeros que son gestores de salud, durante su proceso de formación permanente, pueden desarrollar habilidades para actuar eficazmente en Atención Primaria, reflexionando sobre la práctica y sobre la práctica, decidiendo la necesidad de permanecer en formación para afrontar las cuestiones derivadas de esa misma práctica.

Descriptores: Competencia Profesional; Práctica Profesional; Gestión em Salud; Enfermeras y Enfermeros; Atención Primaria de Salud. 


\section{INTRODUCTION}

Primary health care $(\mathrm{PHC})$ is attributed to health promotion, disease prevention, treatment and rehabilitation actions carried out by a multidisciplinary team to the population living in a defined territory. It is located on the first level of health care, being the main gateway and organizer of the actions and services offered in the health care network. PHC will be offered in full and free of charge to all people, considering health determinants and conditions $s^{(1)}$.

The PHC management process is complex, which requires the development of unique skills from its professionals, as well as knowledge of various contents related to management and specific aspects of the health sector. However, it is clear that health service managers do not always have appropriate technical training, nor do they have a comprehensive understanding of health management, reinforcing the need for preparation to assume this position. Raising the professional practice of managers is essential to qualify the care provided to the subjects, as well as to solve problems related to health care ${ }^{(2)}$.

Other evidence points to nurses in the administrative position of care and in management practice. The professional develops assistance and management actions simultaneously; however, the results demonstrate a break with care due to the numerous activities related to management in the nurse's daily life, which suggests weakness in this level of care. Thus, a challenging reality is manifested in the sense of overcoming fragmented care and centered on the individual/patient ${ }^{(2-3)}$.

Such dissatisfaction in the face of this fragmentation paradigm may favor reflective practice, since, in terms of health management, it is necessary to instigate reflexivity for unpredictable circumstances and actions. Reflective practice, understood as a specific method of work, aims to agree that the professional produces knowledge based on their own professional practice, in their reality ${ }^{(4)}$.

Reflexivity is understood as the constant attention on how the empirical circumstances affect the researcher and his work, the field and social life, and the rupture between the knowledge produced by the one who produced it is not plausible, therefore, the practice of reflexivity is permanent. . There are numerous derivations of the term reflection (reflexivity, practical reflection, reflective thinking, reflection-in-action, etc.), and its understanding is rooted in ancient historical traditions stemming from philosophy and the human and social sciences ${ }^{(5-6)}$.

Through systematic and continuous reflection, we are able to promote the formative dimension of practice. Through practical-reflective teaching, we are able to develop new forms of research on practice and education for practice, in order to "create a moment of its own momentum, or even something that is transmitted by contagion"(7).

Therefore, due to the importance of reflecting on the process of permanent professional training of $\mathrm{PHC}$ nurse managers and its consequences for care, we chose to anchor this study on the relevant theory of reflective practice proposed by Donald Schön, which has been used in the development of a doctoral thesis, of which this article is an excerpt.

Such discussion is justified, since the nested approach of the themes can subsidize and provide theoretical support for advances in the process of permanent training of the nurse manager. Schön's studies problematize issues related to theory-practice in daily professional life, which, in turn, will enable training for continuous reflective practice. The choice of this framework is due to the necessary discussion on the themes "reflection on practice" and "reflective professional" and its importance in terms of the development of skills in health management today. It is assumed that nurse managers, when adding, in their professional training, knowledge about the Unified Health System (SUS - Sistema Único de Saúde), $\mathrm{PHC}$ and reflexivity about their practice, will be more competent management to act.

\section{OBJECTIVES}

To analyze the process of permanent professional training of Primary Health Care nurse managers from the perspective of reflective practice theory, built by Donald Schön.

\section{METHODS}

This is a reflection study, based on a bibliographic search about Donald Schön's theory, based on the posthumous work with wide repercussion in our country, Educating the Reflective Practitioner: Toward a New Design for Teaching and Learning in the Professions, that presents a new perspective to the teaching-learning process through the interaction between theory and practice; since that publication, his profound theory has been used inherently to reflective professional exercise ${ }^{(7)}$. The study was based on the discursive formulation in two moments: The Professional Nurse Manager Training and Reflective Practice: Links with D. Schön's Theory and Development of Competencies in Professional Training for Practice. Thus, it is proposed a reflection on reflective practice as a device for the development of skills for PHC in the training of nurse managers.

\section{RESULTS}

\section{Professional Nurse Manager Training and Reflective Prac- tice: Links with D. Schön's Theory}

Donald Schön's work approach the process of reflection-in-action, a teaching that favors learning through doing, a teaching in which the ability to reflect must be stimulated through teacher-student interaction, in different practical situations. Schön was a Master and Ph.D. in philosophy at Harvard University, having directed his work towards organizational learning and professional effectiveness, and participated in numerous professional organizations.

He criticizes the epistemology of technical rationality, by ensuring that professional practice does not translate into a mere problem-solving process, since in everyday practice, problems are not presented to the professional as data. He defends a reflective professional practice, in which, based on problematic situations, which are the ones that most challenge the professional, the resolution must be constructed. Schön ${ }^{(7)}$, who only through reflective practice "the professional will be able to define a problem, select its elements, determine the limits of his attention in relation to it and be consistent in delineating as possible first in favor of a solution". 
According to this author, professionals should observe and reflect on their actions in the daily professional life in order to solve the problems encountered, "descending to the swamp", realizing the difficulties, and, from there, reflecting to seek solutions for change and for solving the problems encountered. The other professionals who choose firm ground are those who do not seek new solutions or methodologies, remaining in the most comfortable environment of a strictly technical practice.

It is understood that reflection translates into something peculiar to each professional and that it is not enough to solve the problems that arise in daily professional life; however, reflection offers possibilities for expanding knowledge and improving practice from a close look at everyone aspects of practice and through teamwork. Thus, in order to practice reflexivity, one must reflect in practice and on practice, dynamizing the experience through a recreational process and through the perspective of building a new knowledge.

It is believed, therefore, that the possibility of interference in practice through its modification is possible through the opportunity to reflect on actions in all stages of professional life. Reflexivity, therefore, is thinking about what you do, becoming aware of the action, making it intelligible. Schön ${ }^{(7)}$ shows that "the reflection on each attempt and its results prepares the field for the next one, having a critical function". In the reflection-in-action process, we think retrospectively about what we have done, thus discovering how our actions can contribute to an unpredictable result; we can then reflect on the action.

For Schön, it is the junction of values that understands practical situations, that dictates rules for action and establishes what forms an acceptable professional performance. It is the so-called professional artistic talent that assumes an essential role in order to describe professional competence, being understood in terms of reflection-in-action. Therefore, it is through professionals' reflection-in-action vision that a constructionist view of their reality is presented, a view on which they see themselves constructing situations of their practice in all modes of professional competence, not only in exercise of professional artistic talent ${ }^{(7)}$.

Nurse managers must develop technical and socio-political skills in order to be involved in formulating the transformation of the setting in which they operate, with the awareness that their performance cannot be restricted to this setting alone, and should be done in the collective, in the units, reflecting throughout the Health Care Network. These managers become part of and co-responsible for the quality of care transformed by their practice, which is in constant construction and change.

From this perspective, Schön shows that the types of reflection-in-action, through which professionals acquire new understandings of uncertain and conflicting situations in their practice, make us assume that professional knowledge does not solve all situations. These professionals must learn a type of reflection-in-action that goes beyond the rules, building new categories of understanding, action strategies and ways of conceiving problems ${ }^{(7)}$.

In this context, nursing, due to its essentially practical nature, can benefit from this tendency to reflect on practice. However, reflective practice is something that we have seen very timidly in nursing literature despite this characteristic of the profession.
Therefore, only a systematic and continuous reflection is able to promote the formative dimension of practice, considering that the reflective practice presents advantages for permanent training, such as updating, renewal, generation of knowledge, among others, and should be encouraged throughout life ${ }^{(8)}$.

According to Schön ${ }^{(7)}$, to become a reflective professional, it is necessary that there are, on the part of professionals, an intrinsic movement of reflection-in-action, reflection-on-action and reflection on reflection-in-action. Professionals act from the knowledge they already have, adding values to it from the act of thinking about what they did and through a retrospective mental reconstruction, to then transform their practice from a new perception of action, analyzing their own action. They use their knowledge to assess from reflection, what their memory brings about interventions that existed before and new forms of intervention that they may develop. At this juncture, the theoretical and practical knowledge for nursing management in PHC cannot be neglected, since nurses need to reveal examples that occurred in their practical experience to contextualize such knowledge, making it necessary, therefore, for nurse managers to reflect on and in their practice, as previously exposed.

Thus, it appears that, through reflection, thought and action, these professionals, based on reflection on their actions, will strengthen their PHC management practices within SUS in a movement of errors and successes. Such processes complement each other, making the professional training process of nurse managers permanent, favoring the development of management skills, such as decision-making, flexibility and leadership, among others, which will help to carry out the practice.

\section{Development of Competencies in Professional Training for Practice}

In relation to daily work, there is a change from the classic concept of professional qualification to an idea of competence in accordance with the new requirements of the productive sector and the fall in the methods used to adapt people to the labor market. In this sense, the Ministry of Health has emphasized the importance of building academic and professional profiles of skills and abilities to act, qualitative and resolutive, having as reference the objectives of the Sanitary Reform, proposing the ordering of human resource formation for the health sector as active subjects of their own construction ${ }^{(9)}$.

In order for a process of permanent professional training of nurse managers to take place, it is necessary that they carry out critical reflexivity about the practice starting from the action, building new knowledge, developing skills and seeking to effect changes in their professional routine. Professional competence, as a human manifestation that explains professional performance in the work context, allows the confrontation of complex situations, guiding managers to be increasingly responsible for the results, directly influencing their practice.

Therefore, the development of competences occurs through continuous learning. Thus, the emergence of new opportunities is a challenge, since the complexity of the organizational environment can cause inequalities between previous knowledge and the knowledge that needs to be learned. Thus, educational 
institutions can contribute, given their objectives based on social development, which is important when thinking about the management of health services ${ }^{(2)}$.

In order to achieve the development of technical and scientific skills, there is a need for nurse managers themselves to expand their knowledge beyond content, in order to find subsidies to act through a reflective praxis. This fact favors the professional training process, which is supported by practical actions in its daily work in PHC, followed by reflection and analysis of these actions, giving a greater direction to its practice; a way to rethink the way its activities are directed towards the construction of a critical-reflective professional.

Based on the above, it is urgent that, to train critical professionals, capable of developing knowledge, skills and attitudes that make up the competencies to work in PHC management, it will only be possible through a permanent training process aimed at meaningful learning, with a transformation bias and based on libertarian and non-conformist autonomy. Therefore, it is necessary to implement investments, in order to encourage managers and professionals to adhere to such an improvement process as a contribution to SUS qualification; the permanent training movement requires a decision by the subject himself that he needs to remain in this process, regardless of the policies or requirements of others.

In other words, the process of permanent professional training is composed of experiences arising from the processes of initial and continuous training, in addition to the experiences acquired in the exercise of the profession on a daily basis. It is more than a cluster of information used for the transmission of knowledge, aiming to contribute to forming subjects' critical awareness in their social context. Only in this way will it be possible for nurses to build knowledge through theory-practice dialogue.

Spontaneous knowledge arising from certain situations is obtained, in many cases, from observation and reflection on actions. In short, the investment made in human resources in health organizations requires qualification and the development of skills necessary for professional performance in daily work, reverting to the quality of health care and competitiveness in these health organizations ${ }^{(9)}$. Professionals' ability to reflect, based on their own reality, leads them to create their own hypotheses for solving the problems found in their reality, pointing to the importance of continuing education.

Reflective teaching requires a lot of experience from the one who teaches. As the experience is nothing more than a cluster of experiments and an arsenal of a defined area, it is essential to be attentive to reports of experiences from competent professionals. It is in this bias that the seriousness of this element is perceived in Schön's work ${ }^{(7)}$. It is not an easy task, making the necessary interventions while teaching rigorously and without authoritarianism.

Certainly, the development of competencies and skills needed by nurse managers also involves subjects' self-assessment. In this light, it is worth mentioning here the Four Pillars of Learning by Jacques Delors, who say that, in order to achieve the objectives of education, it is essential to organize the teaching-learning process based on four pillars of knowledge: learning to know, learning to do, learn to live together, learn to be, which must develop throughout the person's life, aiming to form a critical and socially active citizen ${ }^{(2)}$.

This foundation, anchored to reflective practice, allows professionals to be trained to deal critically with the complexity of management processes and carry out their practices autonomously, as protagonists, with mutual responsibility, forming solidary bonds and participating collectively in the practices of health, within the broader view of comprehensive health ${ }^{(4)}$.

The concern shown with the development of their own training is demonstrated when professionals initially problematize their own reality and, in the end, return to it in order to transform it, confirming the lived experience. It is perceived that it is necessary to change it, update knowledge, but such change is not always effective, as it implies changes in habits, customs, lifestyle and values.

Therefore, it is inferred that, through reflective thinking about the practice, we can improve it, creating subsidies for our future practices. The correlation between educational practice and professional experience, on a continuous basis, makes learning and teaching incorporated into work processes on a daily basis, favoring the transformation of management practices, with the consequent development of skills. Thus, supported by reflective practice, health managers can, during their permanent training process, develop skills to act effectively in management, following the precepts of $\mathrm{PHC}$.

As a limitation, due to the type of study presented, the reflections were described based on researches' professional experience and on the theory presented, requiring adjustments so that professionals can incorporate and concretize such practices.

\section{Contributions to nursing}

The study's contributions to nursing reside especially in the findings that allow a better understanding of the permanent process of professional training; it is one of the pillars that guide the solutions to complex daily work problems in $\mathrm{PHC}$ through reflective practice, which favors the strengthening of skills and the development of competencies necessary for this work, such as leadership, flexibility, decision-making, among others. It is also hoped that the study can assist in supporting the implementation of permanent education actions and, therefore, changes in the process of professional training and qualification of the assistance provided to SUS users, suggesting, finally, the performance of new studies.

\section{FINAL CONSIDERATIONS}

Studies about reflexivity on professional practice are not recent in the national and international scene; however, it is believed that this theme still needs to be emphasized more broadly, emphasizing the relevance of its applicability in the various contexts of today. These studies prove to be of fundamental importance for the interaction between theory and practice; however, in reality, there is still a departure from the desired reflective practice. Thus, it appears that reflexivity is essential in the health management scenario, but it is still little explored, in view of Donald Schön's new epistemology of practice and the development of fundamental competencies for PHC management, which make up the current theme, given the solidity of this policy that guides SUS. 
Practical experience is also an important factor for continuous learning. The results point to a movement of continuous training, through successes, dilemmas, the successes that occurred during all professional life, through the movement of return to reality in the sense of transforming it. The search for new knowledge, change of attitude, skill strengthening and development of skills such as decision making and leadership appear as a necessity so that one can follow the transformation of practices through reflexivity, something with totally new perspectives. Therefore, there is this need for change, since changing is a question of survival today.
The approached theme is shown to be important, serving as a basis for future studies in an attempt to deepen its practical applicability in different contexts of action, such as health and education. It is worth mentioning the importance of broadening the discussion of these themes, especially in the field of continuing education for nurse managers. In view of the above, it is concluded that reflective practice must be established as a process of constant search from different knowledge, as a way of problematizing questions related to theory and practice, aiming to offer subsidies to find answers to the dilemmas that present themselves in daily practice, thus enabling the strengthening of $\mathrm{PHC}$ management.

\section{REFERENCES}

1. Ministério da Saúde (BR). Departamento de Atenção Básica. Política Nacional de Atenção Básica [Internet]. 2017 [cited 2020 Mar 12]. Available from: https://bvsms.saude.gov.br/bvs/saudelegis/gm/2017/prt2436_22_09_2017.html

2. Nascimento $A B$, Lasevicius $C A$, Santos GAA. Competências necessárias à formação do gestor hospitalar: contribuição dos 4 pilares da educação de Delors. Cad Ed Tec Soc. 2016;9(1):15-27. https://doi.org/10.14571/cets.v9.n1

3. Barbiani R, Nora CRD, Schaefer R. Nursing practices in the primary health care context: a scoping review. Rev Latino-Am Enfermagem. 2016;24:e2721. https://doi.org/10.1590/1518-8345.0880.2721

4. Netto L, Silva KL, Rua MS. Prática reflexiva e formação profissional: aproximações teóricas no campo da Saúde e da Enfermagem. Esc Anna Nery. 2018;22(1):e20170309. https://doi.org/10.1590/2177-9465-EAN-2017-0309

5. Minayo MCS, Guerriero ICZ. Reflexividade como éthos da pesquisa qualitativa. Ciênc Saúde Coletiva. 2014;19(4):1103-12. https://doi. org/10.1590/1413-81232014194.18912013

6. Tardif M, Moscoso JN. A Noção de “Profissional Reflexivo" na Educação: atualidade, usos e limites. Cad Pesquisa. 2018;48(168):388-411. https://doi.org/10.1590/198053145271

7. Schön DA. Educando o Profissional Reflexivo: Um novo design para o ensino e a aprendizagem. Porto Alegre: Artmed; 2000.256 p.

8. Waldow VR. Momento de cuidar: momento de reflexão na ação. Rev Bras Enferm. 2009;62(1):140-5. https://doi.org/10.1590/ S0034-71672009000100022

9. Siqueira-Batista R, Gomes AP, Albuquerque VS, Cavalcanti FOL, Cotta RMM. Education and competences for the Brazilian Unified Health System (SUS):is it possible to find alternatives to the logic of late capitalism? Ciênc Saúde Coletiva. 2013;18(1):159-70. https://doi. org/10.1590/S1413-81232013000100017 